\title{
The Influence of Microbia Time and Types of PGPR on Growth of Soybean Plant (Glycine Max Meril) on Vegetative Phase
}

\author{
Bukhari $^{1}$, Rudi Fadhli ${ }^{2}$, Nuryulsen Safridar ${ }^{3}$ \\ 1,2,3Universitas Jabal Ghafur, Indonesia \\ Email: bukharimp@gmail.com, rudifadhli@unigha.ac.id,nuryulsensafrida@unigha.ac.id
}

\begin{abstract}
:
This research was conducted in the Experimental Garden of the Faculty of Agriculture, Jabal Ghafur Glee Gapui University, Pidie Regency, which took place from September 16 to November 15, 2017. This study used a Completely Randomized Design (CRD) of $2 \times 3$ with 3 replications. The time factor for administration consists of 2 levels : W1 (Pagi), W2 (Sore). Plant Growth Promoting Rhizobacteria (PGPR) type factors consist of three levels: P1 (Rhizobium), P2 (Mikoriza), P3 (Mikoriza + Rhizobium). Parameters observed in soybean plant components include: plant height at ages 15, 30 and 45 HST, root fresh weight, root dry weight, number of nodulations. The difference in the time of administration of PGPR has a very significant effect on root dry weight, but it does not significantly affect the height of plants aged 15, 30 and 45 HST, root fresh weight, root length and number of root nodules, the best treatment was encountered at the time of administration of PGPR W2 (Afternoon). Different types of PGPR have very significant effect on root length and number of nodulations, but no significant effect on plant height aged 15, 30 and 45 HST, root fresh weight and root dry weight. The best treatment was found in the treatment P1 (Rhizobium). There was no interaction between the time of administration of the PGPR and the type of PGPR against all observed parameters.
\end{abstract}

Keywords:

microbia time; types of pgpr; soybean plant; vegetative phase

\section{Introduction}

One type of food crops that can be developed in dry land is soybean (Glycine max Meril), it's just that the limitation factor of soil fertility is an obstacle that needs attention in its management. Some conventional agricultural practices with high inputs on dry land cannot be maintained, this reality requires a solution to overcome these problems so that soybean crop production can be increased, on the other hand its sustainability is guaranteed in the long term (Atman, 2006). Drought stress is a major environmental factor affecting leaf growth, roots, stomata content, photosynthesis and accumulation of dry matter (Zang, 2007). One of the most important structures connecting plants with the environment is stomata with guard cells found in leaf epidermis, and plays a role in tolerance to environmental changes (Schroeder et al, 2001). Furthermore Maghsoudi, (2008) added that drought stress is very influential on the characteristics of plant photosynthesis, this event results in photosynthesis and leaf chlorophyll content being reduced (Feng et al., 2013). The manifestation of plant responses to drought is a complex physics-chemical process and affects the formation of many large and small biological molecules such as nucleic acids, proteins, fats, hormones, free radical ions and minerals (Ingram and Bartels, 2006).

Water stress affects every phase of plant development, however damage caused by stress is more pronounced when it occurs in important growth phases such as germination, 
shoot and root growth, flowering and seed formation (Rauf, 2008).

This problem can actually be overcome by utilizing microbial-based biotechnology taken from sources of biological wealth (Hanafiah et al, 2007). The microbial technology, known as biological fertilizer, is an active biological product consisting of soil-fertilizing microbes to improve fertilizer efficiency, fertility and soil health (Sarwati and Sumarno, 2008). The reasons for health and nature conservation make organic agriculture as an alternative to modern agriculture, which in essence is to manipulate biological bodies in order to play a more effective role in increasing agricultural production. In general, soybeans are planted in rice fields and dry fields, lack of water can inhibit plant growth and reduce yield. The application of mycorrhizae in plants is an effort to overcome stunted growth due to drought stress.

Biotechnology is also a solution to the need for procurement of fertilizers in a cheap and environmentally friendly way, where one of them is by the use of biofertilizers. The content of biological fertilizer is a microorganism that has a positive role for plants, a group of microorganisms that are often used are microbes that tether $\mathrm{N}$ from the air, microbes that dissolve nutrients (especially P and K), microbes that stimulate plant growth (Isrroi, 2008).

Microbes from the group of bacteria used as biofertilizers are referred to as rizobacteria that promote plant growth or are popularly called plant growth promoting rhizobacteria (PGPR), are groups of beneficial bacteria that aggressively "occupy" (colonize) rhizosphere (thin soil between 1-2 $\mathrm{mm}$ around the rooting zone ). PGPR activities provide benefits for plant growth, both directly and indirectly. The direct effect of PGPR is based on its ability to provide and mobilize or facilitate the absorption of various nutrients in the soil as well as to synthesize and change the concentration of various growth promoting phytohormones, while the indirect effect is related to PGPR's ability to suppress pathogenic activity by producing various compounds or metabolites such as antibiotics and siderophore (antibiotics and siderophore) Kloepper et al., 2001).

PGPR lives in rhizospheric areas and plays an important role in plant growth, due to its ability to form colonies around roots quickly (Hasanuddin, 2003). Its functions include helping supply nutrients for plants, facilitating nutrient absorption for plants, helping decomposition of organic matter, providing a better rhizosphere environment, so that in the end it will support growth and increase crop production (Issroi, 2008). Efforts that can be made to overcome this problem are the use of mycorrhizal fungi. Mahbub (2009) states that this fungus is able to dissolve $\mathrm{P}$ which is difficult to dissolve by producing phosphatase enzymes and chelating compounds Al. Mycorrhizal fungi can also increase P uptake due to the presence of external hyphae that have a wide range that can accelerate the availability of $\mathrm{P}$ so that it will be able to increase P uptake of plants.

To get optimal growth and yield of soybean, PGPR is also greatly influenced by the right application time and according to dosage and environmental environmental factors. This is consistent with what was stated by Kelik (2010) that fertilization with the right dose and time will provide optimal results on plants, if the influence of other factors such as temperature, light, etc. are also in optimal conditions.

Based on the description above, it can be seen that the use of soil microorganisms / microbes in increasing nutrient availability is important to study, so it is necessary to conduct research on the use of plant growth enhancing bacteria to increase mycorrhizal infections, nodulation and growth of soybean plants in dry land. 


\section{Research Methods}

The research was carried out in the experimental garden of the Faculty of Agriculture, Jabal Ghafur Sigli University, from September 16 to November 15, 2017. The materials used in this study were: as a growing media consisting of certified Anjasmoro soybean seeds, PGPR (Mycorrhiza and Rhizobium) pesticides Nara. The equipment used in this study includes polybags, hoes, sieves, rakes, scales, counters and writing instruments, other equipment that supports this research.

\section{Discussion}

The results of the variety analysis showed that, when giving PGPR statistically did not significantly affect the age of 15, 30 and 45 HST. But visually there are differences, especially at the age of observation at 45 days. The average height of soybean plants aged 15, 30 and 45 HST due to the time of PGPR administration can be seen in Table 2.

Table 1. Average Height of Soybean Plant Age 15, 30 and 45 HST Due to Time of Giving PGPR

\begin{tabular}{cccc}
\hline \multirow{2}{*}{ Time of Giving PGPR } & \multicolumn{3}{c}{ Plant height $(\mathrm{cm})$} \\
\cline { 2 - 4 } & 15 HST & 30 HST & 45 HST \\
\hline$W_{1}$ & 14,74 & 46,09 & 79,50 \\
$\mathrm{~W}_{2}$ & 15,04 & 49,83 & 86,56 \\
\hline
\end{tabular}

From Table 2 it can be seen that, the average height of soybean plants due to differences in the time of PGPR administration at all age observations was found in the W2 treatment (the time of afternoon administration) which is $15.04 ; 49.83$ and $86.56 \mathrm{~cm}$. While the lower average plants were found in W1 treatment (the time of morning administration), which was 14.74; 46.09 and $79.50 \mathrm{~cm}$.

Although PGPR is given according to the needs of plants (the right application time and according to dosage), but to get optimal growth and yield is also greatly influenced by environmental factors. Consumption of plant nitrogen from nitrogen fixation occurs not at the beginning of the vegetative phase and at the end of the reproductive period, but occurs after the formation of nodules that occur due to rhizosphere colonization and rhizobia infection in the legume root (Beck et al., 2001).

\section{Conclusion}

When giving PGPR has a very significant effect on root dry weight, but it does not significantly affect plant height aged 1530 and 45 HST, root fresh weight, root length and number of root nodules. ). PGPR type has a very significant effect on root length and number of nodulations, but does not significantly affect plant height aged 15, 30 and 45 HST, fresh weight and root dry weight, the best treatment is found in treatment P1 (Rhizobium). There is no real interaction between the time of the administration of PGPR and the type of PGPR against all observed parameters. 


\section{References}

Adijaya, I. N, Suratmi, P dan Mahaputra, K. 2004. Aplikasi Pemberian Legin (Rhizobium) Pada Uji Beberapa Varietas Kedelai Di Lahan Kering.Balai Pengkajian Teknologi Pertanian Bali

Adisarwanto. 2008. Budidaya Kedelai.Penebar Swadaya. Jakarta.

Atman. 2006. Pengelolaan Tanaman Kedelai di Lahan Kering Masam. Jurnal Ilmiah Tambua 3 : 281-287

Badaruddin, 2005. Penyaringan Ketahanan Kacang Terhadap Salinitas Dengan Menggunakan $\mathrm{NaCl}$. Jurusan Budidaya Pertanian, Fakultas Pertanian dan Kehutanan, Universitas Hasanuddin, Makassar.

Cahyono.2007. Teknik Budidaya dan Analisis Usaha Tani Kedelai. Aneka Ilmu. Semarang.

Couto, C., Silva, L.R., Valentão, P., Velázquez, E., Peix, A., Andrade, P.B., 2011. Effects induced by the nodulation with Bradyrhizobium japonicum on Glycine max (soybean) metabolism and antioxidant potential. Food Chem. 127, 1487-1495.

Dwijoseputro. 2005. Pengantar Fisiologi Tanaman. Jakarta : Gramedia

Fachruddin, 2000. Budidaya kacang-kacangan. Kanisius, Yogyakarta.

Frederick LR. 2005. Soybean inoculation. In: Expanding the Use of soybean. RM Goodman (ed). Intern. Agr. Pub. Collage of Agriculture Univesity of illinois. Univ. Press. Urbana campaign.

Gardner, F. P., Pearce, R. B., dan Mitchell, R. L. 2001. Fisiologi Tanaman Budidaya. Universitas Indonesia (UI-Press) : Jakarta.

Gunalan. 2006. Pengunaan Mikroba Bermanfaat Pada Bioteknologi Tanah Berwawasan Lingkungan. Majalah Sriwijaya Vol.32. No .2 Universitas Sriwijaya.

Islam, F., Yasmeen, T., Riaz, M., Arif, M.S., Ali, S., Raza, S.H., 2014b. Proteus mirabilis alleviates zinc toxicity by preventing oxidative stress in maize (Zea mays) plants. Ecotoxicol. Environ. Saf. 110, 143-152.

Hanafiah, KA. Napoleon, N. Ghofar. 2007. Biologi Tanah : Ekologi dan MakrobiologiTanah : Edisi 1-2. PT. Rajawali Grafindo Persada, Jakarta.

Hermastini. 2007. Trubus Majalah Pertanian Indonesia (http://www.trubus. online.co.id, diakses 24 November 2017 pukul. 13.30 WIB

Islam, F., Yasmeen, T., Riaz, M., Arif, M.S., Ali, S., Raza, S.H., 2014b. Proteus mirabilis alleviates zinc toxicity by preventing oxidative stress in maize (Zea mays) plants. Ecotoxicol. Environ. Saf. 110, 143-152.

Isroi. 2008. Bioteknologi Mikroba Untuk Pertanian Organik. Badan Penelitian Dan Pengembangan Pertanian.info@litbang.pertanian.go.id.Jakarta Selatan.

Jutono, 2001. Fiksasi Nitrogen (N2) Pada leguminosae dalam pertanian (suatu pedoman untuk Inokulasi). Lab Mikrobiologi Fakultas Pertanian,Universitas Gajah Mada, Jogyakarta.

Kennedy, A.C.2008. The rhizosphere and spermosphere. p. 389-407. In Silvia et al. (Eds.). Principles and Application of Soil Microbiology.Prentice Hall. New Jersey.

Kloeper J and Schroth. 2001. Plant growth promoting rhizobacteria onn radiesshes.p.879882.In Angrs (ED.). Proceedings of the Fourth International Conference on Plant Pathogenic bacteria.

Loveless. 2001. Prinsip-prinsip Biologi Tumbuhan untuk Daerah Tropika 1. Jakarta: PT. Garamedia Pustaka Utama.

Maghsoudi, K and Maghsoudi, A. 2008. Analysis of the Effects Stomatal Frequency and Size on Transpiration and Yeild of Wheat (Triticum aestivum L.) Am. Eur. J. Agric. Environ Sci. 3: 579-586.

Mehta, 2008. Variabilitas Genetik, Heritabilitas, dan Penampilan Fenotipik 18 Klon Mawar Cipanas. Zuriat 3 No.11 
Novriani 2011. Peranan Rhizobium dalam Meningkatkan Ketersediaan Nitrogen bagi Tanaman Kedelai. AgronobiS, Vol. 3, No. 5, ISSN: 1979 - 8245X

Powell, 2007: Moderní technologie ošetření obilek lipnice luční, Zahradnictví, Měsíčník pro profesionální zahradníky. Odborný recenzovaný časopis, 7: 40-41. ISSN 1213-7596.

Purwanti, S. 2007. Usaha Meningkatkan Kuantitas dan Kualitas Hasil Benih Kacang Hijau (Vigna radiata (L.) Willczek) Dengan Inokulasi Rhizobium dan Pupuk TSP.

Rachmaniar, A.M., 2007. Variasi Somaklon Tebu Tahan Kering dengan Polyetylen Glycol (PEG) secara In vitro. Thesis Program Pasca Sarjana Universitas Hasanuddin, Makassar, Tidak Dipublikasikan.

Rauf. A.W., Syamsuddin, T., dan S.R. Sihombing., 2000. Peranan PupukNPK Pada Tanaman Padi. Departemen Pertanian. Balitbang.Irian Jaya.

Schroeder JI, GJ Allen., V. Hugouvieux, JM Kwak, dan D. Waner. 2001. Melindungi transduksi sinyal sel. Tinjauan Tahunan Fisiologi Tumbuhan dan Biologi Molekuler Tumbuhan. 52: 627-658.

Silalahi, H. 2009. Pengaruh Inokulasi Rhizobium Dan Pupuk Fosfat Terhadap Pertumbuhan Dan Hasil Kedelai (Glycine max L. Merril). Skripsi dipublikasikan. Departemen Budidaya Pertanian Fakultas Pertanian Universitas Sumatera Utara Medan.

Suprapto, 2009. Bertanam kedelai. Penebar Swadaya, Jakarta.

Sutanto. 2002. Pertanian organik. Kanisius. Yogyakarta.

Tiwari, S., Lata, C., Chauhan, P.S., Nautiyal, C.S., 2016. Pseudomonas putida attunes morphophysiological, biochemical and molecular responses in Cicer arietinum L. during drought stress and recovery. Plant Physiol. Biochem. 99, 108-117.

Trape dan N.C Scheneck.2002. Taxonomyof The Fungi Forming Endomycorrhizal dalam Nc Schecnk (ed). Methode and Principles of Mychorrhizal Research.APS.St.Paul MN.

Upadhyay, S.K., Singh, J.S., Saxena, A.K., Singh, D.P., 2012. Impact of PGPR inoculation on growth and antioxidant status of wheat under saline conditions. Plant Biol. 14, 605611.

Vass, I., 2012. Molecular mechanisms of photodamage in the Photosystem II complex. BBABioenergetics 1817, 209-217.

Vest G, DH Weber and C Sloger. 2006. Noduation andnitrigen fixation. In: Soybeans, Inprovementproduction and Uses. B;E. Cadwell (ed). 353-390. Inc. Madison. Wisconsin, USA.

Yutono. 2005. Inokulasi Rhizobium pada Kedelai. Dalam Somatmadji. Kedelai. Balai Penelitian dan Pengembangan Pertanian. Puslitbangtan. Hlm.217- 230.

Zang. 2007. Instructions and tables for Computing potential evapotranspiration and the water balance. Publication. in Climatology. Vol. X, No.3. Drexel Inture of Tecnology Laboratory of Climatology, Centerton, New Jersey. pp.185-311. 